\title{
The effects of maternal intake and gestational age on materno-fetal transport of vitamin $\mathrm{C}$ in the guinea-pig
}

\author{
S. Das and H. J. Powers* \\ Division of Child Health, University of Sheffield, Sheffield S10 2TH, UK
}

(Received 10 November 1997 - Revised 30 March 1998 - Accepted 15 May 1998)

\begin{abstract}
The effects of maternal intake and gestational age on materno-fetal transport of vitamin $\mathrm{C}$ were investigated in female Dunkin-Hartley guinea-pigs. Twenty-four time-mated dams were fed on either a moderate-vitamin C (group A) or a high-vitamin C (group B) diet, throughout pregnancy. At days 49, 63 and 66 of gestation, and at term, three animals from each group were killed and fetuses removed by hysterectomy. Plasma, liver, kidney, lungs, heart, placenta and amniotic fluid were collected from dams and fetuses and subsequently analysed for vitamin C. Fetal plasma and amniotic fluid concentrations showed negative associations with gestational age for both dietary groups, independent of an effect of dam $(P<0 \cdot 001)$. A similar, though not significant, effect of gestational age was observed on placental vitamin $\mathrm{C}$ and group A fetal tissue concentrations. Fetal plasma, placental and amniotic fluid vitamin $\mathrm{C}$ concentrations were significantly higher in group B than group A $(P<0 \cdot 001)$, suggesting the influence of maternal diet. Although the level of maternal vitamin $\mathrm{C}$ intake can influence the circulating concentration in the fetus, there is a decrease associated with increasing gestational age, independent of the maternal diet. The gestational age-dependent change in the fetal accumulation of vitamin $\mathrm{C}$ may reflect changes in the rate of placental transfer.
\end{abstract}

\section{Vitamin C: Materno-fetal transport: Guinea-pig}

Babies born preterm have a higher circulating concentration of vitamin C than babies born at term (Silvers et al. 1994; Berger et al. 1996). In view of the evidence that free radicals play a role in the pathophysiology of certain diseases of prematurity (Kelly \& Lubec, 1995; Saugstad, 1996), a high plasma concentration of vitamin $\mathrm{C}$, a known antioxidant, might be expected to confer some benefit. There is, however, interest in the possibility that at high concentration in the plasma of premature babies, vitamin $\mathrm{C}$ may act as a prooxidant. A large longitudinal study in premature babies has suggested that a high concentration of plasma vitamin $\mathrm{C}$ in the neonatal period is associated with poor outcome (Silvers et al. 1998). At concentrations measured in the plasma of premature babies vitamin $\mathrm{C}$ inhibits the antioxidant activity of caeruloplasmin (Gutteridge, 1991; Powers et al. 1995). Low concentrations of transferrin and caeruloplasmin (Lindeman et al. 1989, 1992, 1995; Silvers et al. 1994), and the presence of catalytic $\mathrm{Fe}$ in the plasma of premature babies (Kime et al. 1996) increase the likelihood that vitamin $\mathrm{C}$ may act pro-oxidatively in this group.

Plasma vitamin C concentrations at birth may be partly a function of gestational age (Silvers et al. 1994) but may also be influenced by maternal vitamin $\mathrm{C}$ intake during pregnancy (Pate et al. 1996). A study was undertaken to explore this.

\section{Materials and methods}

\section{Reagents}

Metaphosphoric acid (MPA) was obtained from BDH laboratory supplies, Poole, Dorset, UK. Hypnorm was obtained from Janssen Animal Health, Janssen Pharmaceuticals Ltd., Grove, Oxon., UK and sodium pentobarbitone from J. M. Loveridge plc, Southampton, Hants., UK. Ascorbic acid oxidase (EC 1.10.3.3), ascorbic acid, phenylenediamine and sodium acetate trihydrate were obtained from Sigma Chemical Co., Poole, Dorset, UK.

\section{Animals and diets}

As the purpose of the study was to understand determinants of high plasma concentrations of vitamin $\mathrm{C}$ in the neonate, it was planned to place pregnant guinea-pigs on a diet either containing adequate vitamin $\mathrm{C}$ or supplemented to give a high vitamin $\mathrm{C}$ content. Due to problems encountered with a commercial diet the basal diets used were not the same (Table 1). All nutrients were considered adequate for normal breeding purposes.

Diet A was a commercial pelleted guinea-pig breeding diet containing $300 \mathrm{mg}$ ascorbic acid/kg diet (SDS, Witham, 
Table 1. Compositions of the diets used in the present study

\begin{tabular}{|c|c|c|}
\hline Nutrients & Diet A & Diet B \\
\hline Crude fat $(\mathrm{g} / \mathrm{kg})$ & 48 & 45 \\
\hline Crude protein $(\mathrm{g} / \mathrm{kg})$ & 189 & 160 \\
\hline Crude fibre $(\mathrm{g} / \mathrm{kg})$ & 129 & 130 \\
\hline Ash (g/kg) & 90 & 84 \\
\hline Gross energy (MJ/kg) & $14 \cdot 2$ & $14 \cdot 5$ \\
\hline \multicolumn{3}{|c|}{ Minerals and trace elements ( $\mathrm{mg} / \mathrm{kg}$ diet) } \\
\hline Iron & 212 & 173 \\
\hline Copper & 12 & 18 \\
\hline Manganese & 86 & 85 \\
\hline Zinc & 124 & 80 \\
\hline Cobalt & 0.40 & 0.62 \\
\hline lodine & 0.992 & $1 \cdot 740$ \\
\hline Selenium & 0.256 & 0.300 \\
\hline Fluorine & 0.019 & - \\
\hline \multicolumn{3}{|l|}{ Vitamins (mg/kg diet) } \\
\hline Retinol & 3.636 & $7 \cdot 500$ \\
\hline Cholecalciferol & 0.021 & 0.050 \\
\hline dl- $\alpha$-Tocopherol & 82 & 142 \\
\hline Thiamin hydrochloride & $17 \cdot 5$ & $21 \cdot 0$ \\
\hline Riboflavin & $23 \cdot 4$ & $25 \cdot 0$ \\
\hline Pyridoxine hydrochloride & $18 \cdot 1$ & $18 \cdot 0$ \\
\hline Cyanocobalamin & $0 \cdot 18$ & 0.04 \\
\hline Ascorbyl polyphosphate & 300 & 5050 \\
\hline Menadione sodium bisulfite & 114 & 35 \\
\hline Pteroylmonoglutamic acid & $6 \cdot 4$ & $11 \cdot 0$ \\
\hline Nicotinic acid & $78 \cdot 4$ & $80 \cdot 0$ \\
\hline Pantothenic acid & $28 \cdot 4$ & $30 \cdot 0$ \\
\hline Choline & 1187 & 1142 \\
\hline Inositol & 1582 & 1580 \\
\hline Biotin & 0.236 & 0.298 \\
\hline \multicolumn{3}{|l|}{ Salts ( $\mathrm{g} / \mathrm{kg}$ diet) } \\
\hline Calcium & 12 & 13 \\
\hline Phosphorus & $7 \cdot 5$ & $5 \cdot 0$ \\
\hline Sodium & $3 \cdot 0$ & $1 \cdot 6$ \\
\hline Chlorine & $4 \cdot 6$ & $3 \cdot 6$ \\
\hline Magnesium & $4 \cdot 8$ & $3 \cdot 0$ \\
\hline
\end{tabular}

Essex, UK). Diet B consisted of a powdered basal diet (B\&K Universal Ltd., Grimston, Aldborough, Hull, UK) containing only $50 \mathrm{mg}$ ascorbic acid/kg diet, supplemented with $5000 \mathrm{mg}$ ascorbic acid/ $\mathrm{kg}$ diet. This was added dry to the powdered diet, which was then mixed and vegetable oil added (about $20 \mathrm{ml} / \mathrm{kg}$ ) to make it palatable to the guineapigs. This diet was made up fresh every $2-3 \mathrm{~d}$ and stored at $4^{\circ}$ whilst not in use. The concentration of vitamin $C$ was $17-$ fold higher in diet B than diet A. There were differences in the concentrations of fat-soluble vitamins between the two diets but there is no basis for believing that this would influence vitamin $\mathrm{C}$ metabolism. Tap water containing $100 \mathrm{mg}$ ascorbic acid/l for diet $\mathrm{A}$ and $1 \mathrm{~g}$ ascorbic acid/l for diet $\mathrm{B}$ was made available for the animals to drink $a d$ libitum. Both groups also received dried autoclaved hay, fresh every $2-3 \mathrm{~d}$. The ascorbic acid content of both diets was confirmed early in the experiment by extraction into MPA $(50 \mathrm{~g} / \mathrm{l})$ and analysis as for tissue samples.

Twenty-four time-mated Dunkin-Hartley guinea-pigs were obtained from David Hall (Darley Oaks Farm, Newchurch, Nr Burton on Trent, Staffs., UK), and were randomly allocated to group A or group B. From 2-3d after time-mating the animals were housed in two large floor pens in a room maintained at a temperature of $22^{\circ}$ with a $12 \mathrm{~h}$ light-dark cycle. All the animals were fed ad libitum.
Time-mating permitted study of the dams and fetuses at specific points in gestation.

\section{Protocol}

The guinea-pig has an average gestation of $72 \mathrm{~d}$. Guinea-pig fetuses were removed on days 49, 63 and 66 of gestation. Day 49 was considered to be the earliest time point at which efficient fetal blood sampling could be guaranteed; gestation for 63 and $66 \mathrm{~d}$ represented prematurity (Kelly et al. $1991 a, b)$. Fetuses were to be removed from three dams at each of these gestational ages from both groups A and B. Pups from the three remaining dams in each diet group were to be delivered naturally at term.

On the day of delivery dams were anaesthetized by subcutaneous administration of $800 \mu$ l hypnorm-diazepam $(50: 50, \mathrm{v} / \mathrm{v})$. Fatal intravenous injection of $500 \mu \mathrm{l}$ sodium pentobarbitone was then given to the animal approximately 20 min afterwards while the animal was fully anaesthetized. Cardiac puncture was then performed followed by exsanguination. The blood was collected into vials containing lithium heparin and immediately stored on ice. The following maternal organs were collected, washed in isotonic saline $(9 \mathrm{~g} \mathrm{NaCl} / 1)$, and weighed: heart, liver, lungs and kidney. A small slice of each of these tissues was removed and stored with an equal amount by volume of $50 \mathrm{~g} / \mathrm{l} \mathrm{MPA}$, to stabilize vitamin C. Samples were immediately placed on solid $\mathrm{CO}_{2}$, and stored at $-70^{\circ}$ until analysis of vitamin $\mathrm{C}$ content. The tissue handling procedure was carried out for all tissues collected throughout the experiment. Following collection of the required maternal organs the fetuses were removed by hysterectomy. Where possible, amniotic fluid was collected from each pup and frozen at $-70^{\circ}$ with an equal volume of $50 \mathrm{~g} / \mathrm{l} \mathrm{MPA}$ for later analysis of vitamin C concentration. Cardiac puncture was performed on each of the fetuses, the blood collected into lithium heparin and stored immediately on ice. This was done within approximately 10 min of initial administration of the fatal sodium pentobarbitone dose to the dam. The heart, liver, lungs, kidneys and placenta were collected from each pup and treated in the same manner as described previously for the dam's tissues. Blood was centrifuged at $13000 \mathrm{~g}$ for $5 \mathrm{~min}$ at $4^{\circ}$, and the plasma placed into nine volumes of $50 \mathrm{~g} / \mathrm{l}$ MPA and stored at $-70^{\circ}$.

After thawing, all samples were kept at $4^{\circ}$ during any subsequent processing to minimize oxidation of vitamin $\mathrm{C}$.

\section{Vitamin C analysis}

Vitamin C concentration was measured in MPA extracts of all the plasma and tissue samples collected. Tissue extracts were prepared by homogenizing (Ultra-Turrax homogenizer, Janke and Kunkel KG, Ikawerke, Straufen I Breigau, Germany) each frozen tissue sample with nine volumes of $50 \mathrm{~g} / \mathrm{l}$ MPA, followed by centrifugation at $13000 \mathrm{~g}$ for $5 \mathrm{~min}$ at $4^{\circ}$, and the supernatant fractions were collected. Vitamin $\mathrm{C}$ analysis was performed by the method of Vuillemier \& Keck (1989) on the Cobas Bio centrifugal analyser (Roche Products Ltd., Welwyn Garden City, Herts., UK). This method relies on the oxidation of ascorbic 
acid to dehydroascorbic acid by ascorbic acid oxidase. The dehydroascorbic acid is then coupled to 1,2-phenylenediamine to produce a fluorescent product which is measured at an excitation wavelength of $350 \mathrm{~nm}$ and an emission wavelength of $430 \mathrm{~nm}$. An internal quality control was prepared from human plasma, stored at $-70^{\circ}$ and included in each sample run. The within-batch $\mathrm{CV}$ for this measurement was $1.6 \%$, the between-batch CV, $2.8 \%$.

\section{Statistical methods}

All the data were stored on Excel 5.0 (Microsoft Ltd., Wokingham, Berks., UK) and analysed using SPSS for Windows, release 6.0 (SPSS UK Ltd., Woking, Surrey, UK). Two-way ANOVA was used to determine the effects of diet and gestational age on vitamin $\mathrm{C}$ concentrations in plasma and tissues. Post-hoc analysis was carried out using the Scheffé test. Associations between variables were explored using regression analysis. Where data for pups were included, a multiple regression analysis was performed in which dam was included in the analysis as a blocking factor.

\section{Results}

Table 2 summarizes the number of animals used in the experiment. One of the dams fell sick and was humanely killed; two were found not to have conceived. The number of pups born to each dam ranged between one and eight, with a median of four. The size of a litter did not determine the plasma ascorbic acid level in the pups.

\section{The influence of gestational age on plasma vitamin $C$ concentrations}

Fig. 1 shows the effect of gestational age on dam plasma vitamin $\mathrm{C}$ concentrations. There was a significant negative association between dam plasma vitamin $\mathrm{C}$ concentration and gestational age for group B $(P=0.0089)$ but not for group A.

In both dietary groups fetal plasma vitamin $\mathrm{C}$ concentrations at $49 \mathrm{~d}$ were several times greater than at any other time point in either the fetuses or the dams (Fig. 2). With increasing gestational age there was a decrease in plasma vitamin $\mathrm{C}$ concentration in both dietary groups. Group A fetuses showed an initial decline of $83 \%$ between day 49 and day 63 and relatively little variation thereafter. In group B fetuses, after correcting for the effect of dam, this association was linear and was statistically significant $(P<0 \cdot 001)$.

Table 2. Numbers of dams and their fetuses completing the study*

\begin{tabular}{lccccc}
\hline & \multicolumn{2}{c}{ Group A } & & \multicolumn{2}{c}{ Group B } \\
\cline { 2 - 3 } Gestational age & Dams & Fetuses & & Dams & Fetuses \\
\hline $49 \mathrm{~d}$ & 3 & $4,6,8$ & & 3 & $4,5,6$ \\
$63 \mathrm{~d}$ & 2 & 4,3 & & 3 & $6,5,4$ \\
$66 \mathrm{~d}$ & 3 & $3,1,6$ & & 2 & 2,4 \\
Term & 2 & 2,3 & & 3 & $8,3,3$ \\
\hline
\end{tabular}

${ }^{*}$ For details of diets and procedures, see Table 1 and pp. 485-487.

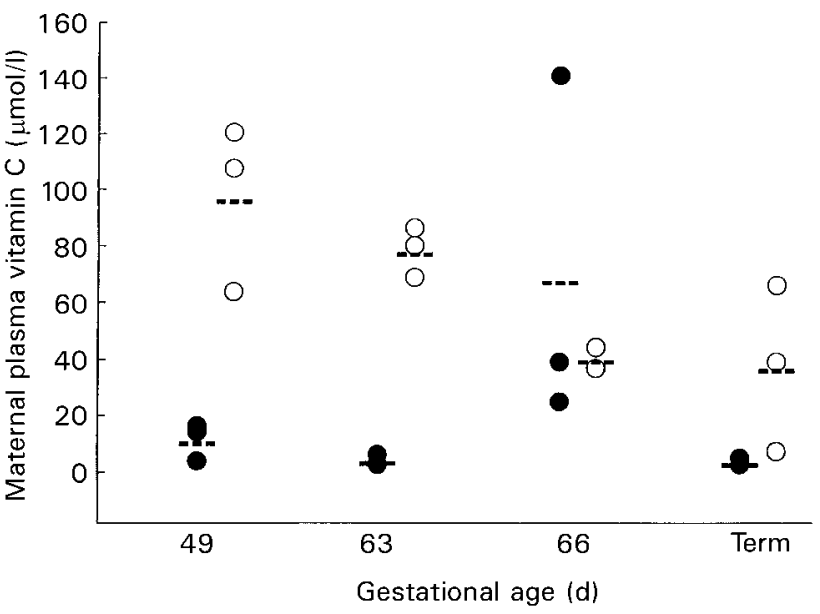

Fig. 1. Plasma vitamin $C$ concentrations throughout gestation measured in guinea-pig dams fed on either a moderate- (group A, ๑) or high(group B, O) vitamin $\mathrm{C}$ diet. Values are for individual guinea-pigs, with medians indicated by a broken line. Group B dams had higher vitamin C concentrations than group A dams at all time points $(P<0.001)$. For details of diets and procedures see Table 1 and pp. 485-487.

\section{The effect of maternal vitamin $C$ intake on plasma vitamin $C$ concentrations in dams and fetuses}

At $49 \mathrm{~d}, 63 \mathrm{~d}$ and at term, all the group A dams had lower plasma vitamin $\mathrm{C}$ concentrations than all group B dams (Fig. 1). One of the three dams killed at $66 \mathrm{~d}$ had unexpectedly high concentrations of plasma vitamin $\mathrm{C}$ for which we have no explanation. Results for the pups of this dam were not outliers. There was a clear effect of maternal diet on maternal plasma vitamin $\mathrm{C}$ concentration, but the few data points precluded statistical analysis. This effect of maternal diet was also seen in the fetuses (Fig. 2). The concentration of plasma vitamin $\mathrm{C}$ in fetuses from group $\mathrm{A}$ was significantly lower than in fetuses from group B at all points in

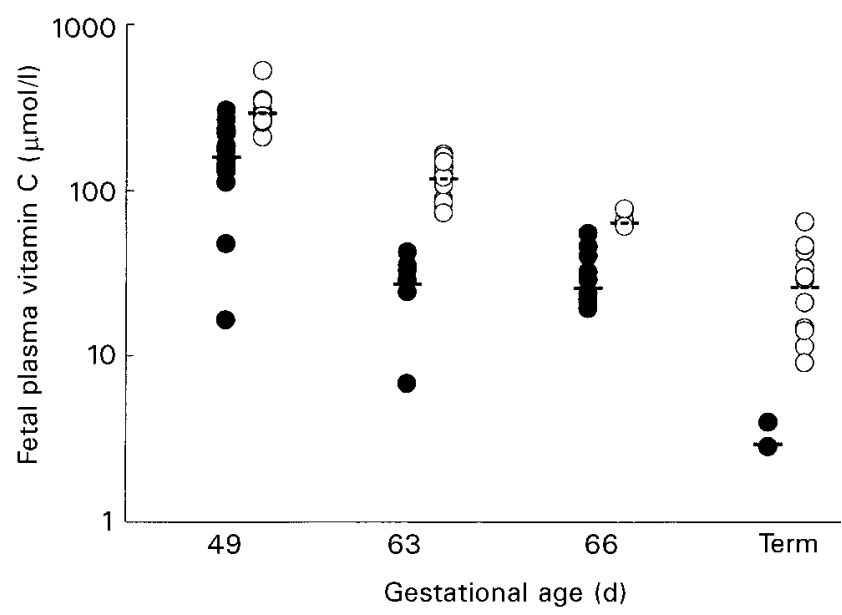

Fig. 2. Plasma vitamin $C$ levels at different points in gestation in fetuses of dams fed on either a moderate- (group A, $\bullet$ ) or high- (group $B, O$ ) vitamin $C$ diet. Values are plotted on a logarithmic scale. Values are for individual fetuses, with means indicated by a broken line. Values for fetuses from group $B$ were higher than those for group $A$ at all time points $(P<0.001)$. For details of diets and procedures see Table 1 and pp. $485-487$. 

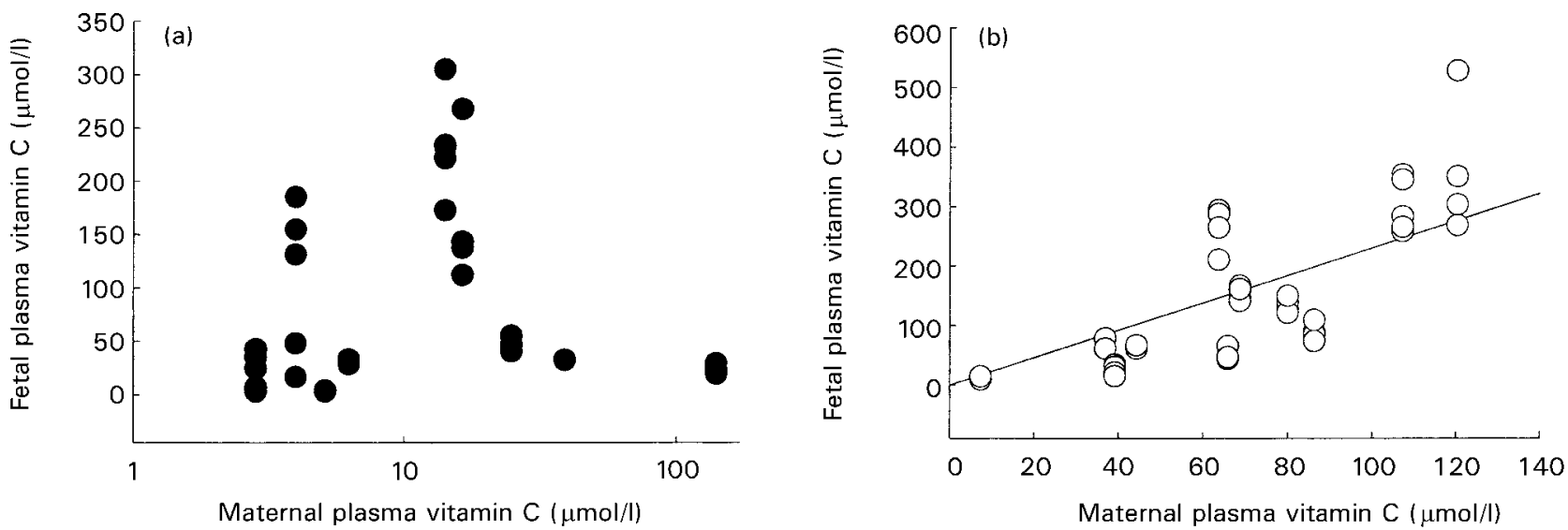

Fig. 3. Relationship between maternal plasma and fetal plasma vitamin $\mathrm{C}$ concentrations in guinea-pigs on (a) a moderate (group A, $\bullet$ ) or (b) a high (group B, $O$ ) vitamin $C$ intake. Group A values are plotted on a logarithmic scale. This association was significant for the high-intake group, independent of dam number $(P=0.0065)$. For details of diets and procedures see Table 1 and pp. 485-487.

gestation $(P<0 \cdot 001)$. Throughout gestation all the fetuses maintained higher plasma vitamin $\mathrm{C}$ concentrations than their respective dams. For group B there was a significant positive association between fetal and dam plasma vitamin C concentrations, independent of dam, which is shown in Fig. 3(b) $(P=0 \cdot 0065)$. This association was not evident for group A.

Fig. 4 shows the ratio fetal : maternal vitamin $\mathrm{C}$ concentrations throughout gestation in both groups. The ratios in both groups showed a significant negative correlation with gestational age, independent of dam (group A, $P=0.0005$; group $\mathrm{B}, P=0.0003$ ). There was also an effect of maternal vitamin $C$ intake; the fetal : maternal ratio was significantly higher in group A than group B at 49 and $63 \mathrm{~d}$ gestation $(P<0.001)$. These group differences had disappeared by $66 \mathrm{~d}$.

\section{The influence of gestational age and diet on tissue vitamin $C$ concentrations}

Dam tissue vitamin C concentrations are shown in Table 3. Median values were higher for vitamin $\mathrm{C}$ concentrations in the liver and lung than the kidney and heart regardless of diet. There were no striking differences in tissue vitamin C concentrations between the two dietary groups at any time point. Median concentrations of vitamin $\mathrm{C}$ in tissues from dams receiving a moderate-vitamin $\mathrm{C}$ diet were lower at term than earlier in gestation.

Vitamin C concentrations in tissues from fetuses at different stages in gestation are shown in Table 4. Maternal diet did not appear to exert any consistent effect on fetal tissue concentrations. One-way ANOVA, followed by the Scheffé test, showed that in group A fetuses the tissue concentrations of vitamin $\mathrm{C}$ were higher at $49 \mathrm{~d}$ gestation than all other time points $(P<0.05)$. In fetuses from dams receiving a high vitamin $\mathrm{C}$ intake, this pattern was only evident for the liver. In contrast, in this group there was an increase in mean tissue vitamin $\mathrm{C}$ from $66 \mathrm{~d}$ to term in all tissues. This was significant for liver and lung $(P<0 \cdot 05)$.

\section{The influence of diet and gestational age on vitamin $C$ concentrations in amniotic fluid}

Figs. 5(a) and 5(b) show amniotic fluid vitamin C concentrations throughout gestation in groups $\mathrm{A}$ and $\mathrm{B}$ respectively (notice the different scales for the $y$ axes). There was a strong negative correlation between vitamin $\mathrm{C}$ concentration and gestational age for both groups $(P<0.001)$ independent of dam. Amniotic fluid from group $B$ had a significantly higher vitamin $\mathrm{C}$ concentration than that from group A at all time points $(P<0 \cdot 001)$.

\section{The influence of diet and gestational age on vitamin $C$ concentrations in placenta}

The placenta showed some of the highest vitamin $\mathrm{C}$ concentrations measured in any of the fetal tissues. Fig. 6 shows that maternal vitamin $\mathrm{C}$ intake influenced concentrations in

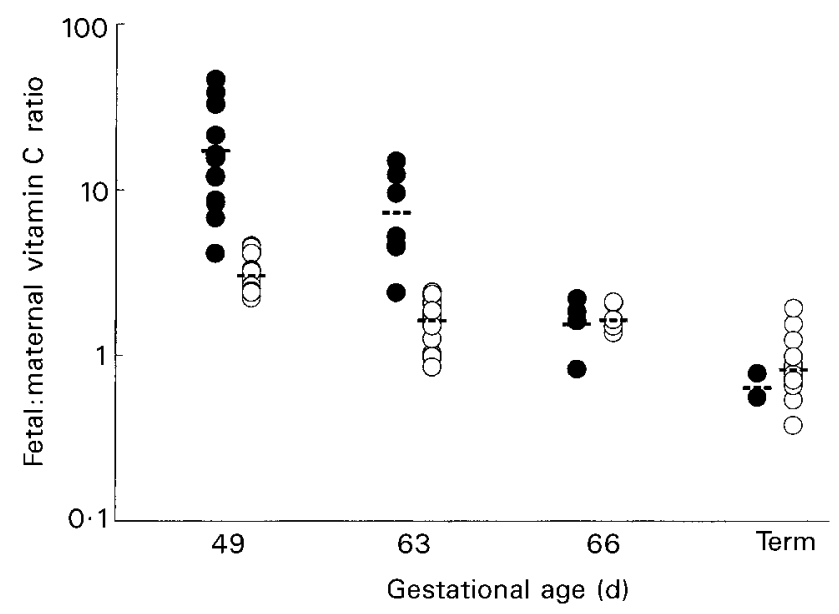

Fig. 4. Fetal : maternal vitamin $C$ concentrations throughout gestation in guinea-pigs fed on either a moderate- (group $A, \bullet$ ) or high- (group $\mathrm{B}, \mathrm{O}$ ) vitamin $\mathrm{C}$ diet. Values are plotted on a logarithmic scale.Values are for individual guinea-pigs, with means indicated by a broken line. Two-way ANOVA showed a significant effect of diet and gestational age $(P<0.001)$. For details of diets and procedures see Table 1 and pp. 485-487. 
Table 3. Concentration of vitamin $C$ in tissues of dams given different amounts of vitamin C during pregnancy (Median values for two or three guinea-pigs, with ranges in parentheses)

\begin{tabular}{|c|c|c|c|c|c|}
\hline \multirow[b]{2}{*}{ Diet } & \multirow[b]{2}{*}{ Gestational age } & \multicolumn{4}{|c|}{ Vitamin $\mathrm{C}$ concentration ( $\mu \mathrm{mol} / \mathrm{g}$ wet wt) } \\
\hline & & Liver & Kidney & Lung & Heart \\
\hline Moderate vitamin C (A) & $\begin{array}{l}49 d \\
63 d \\
66 d \\
\text { Term }\end{array}$ & $\begin{array}{c}1269(1109-1698) \\
1037(1030-1044) \\
1626(1026-1664) \\
772(717-864)\end{array}$ & $\begin{array}{l}365(362-1192) \\
300(284-316) \\
548(403-1198) \\
225(271-325)\end{array}$ & $\begin{array}{c}1367(1270-1439) \\
1099(1024-1174) \\
1361(1174-1464) \\
792(715-915)\end{array}$ & $\begin{array}{l}589(266-2537) \\
223(214-231) \\
365(255-623) \\
214(181-211)\end{array}$ \\
\hline High vitamin $\mathrm{C}(\mathrm{B})$ & $\begin{array}{l}49 \mathrm{~d} \\
63 \mathrm{~d} \\
66 \mathrm{~d} \\
\text { Term }\end{array}$ & $\begin{array}{l}1776(1578-1877) \\
2184(1686-2211) \\
2080(1547-2613) \\
1425(1018-1661)\end{array}$ & $\begin{array}{l}631(488-1712) \\
530(455-533) \\
565(480-650) \\
532(209-747)\end{array}$ & $\begin{array}{c}501(366-1686) \\
2075(1900-2090) \\
949(851-1047) \\
1559(972-2188)\end{array}$ & $\begin{array}{l}229(123-376) \\
489(484-750) \\
288(235-341) \\
435(375-518)\end{array}$ \\
\hline
\end{tabular}

${ }^{*}$ For details of diets and procedures, see Table 1 and pp. 485-487.

the placenta. Although for both groups, there was a trend towards a fall in vitamin $\mathrm{C}$ as gestation progressed, after correcting for dam the associations failed to reach significance. Placentas from fetuses in group B had significantly higher vitamin $\mathrm{C}$ concentrations than those from group $\mathrm{A}$ at each point in gestation $(P<0 \cdot 001)$.

\section{Discussion}

\section{Differences in plasma, amniotic fluid and tissue vitamin $C$} concentrations attributable to gestational age

Irrespective of maternal vitamin $\mathrm{C}$ intake, concentrations of vitamin $\mathrm{C}$ in fetal plasma and tissues showed a similar pattern. The concentration of vitamin $C$ was higher at $49 \mathrm{~d}$ than at later points in gestation. The fall was greatest between $49 \mathrm{~d}$ and $63 \mathrm{~d}$ for plasma and all tissues. For group A fetuses the concentration of vitamin $\mathrm{C}$ in all tissues was significantly greater than at all subsequent time points. A fall in fetal tissue concentration might be expected if the rate of transport to each fetus was unable to increase in response to increasing fetal mass. The fall in fetal plasma vitamin $\mathrm{C}$ concentration towards term would explain the higher concentration of plasma vitamin $\mathrm{C}$ in babies born preterm compared with babies born at term. The gestationrelated fall in tissue vitamin $\mathrm{C}$ was curiously reversed at about term in pups born to mothers receiving the high-vitamin $\mathrm{C}$ diet, among whom there was a consistent increase in tissue vitamin $C$ between day 66 and term. The mechanism for this is unclear, but as plasma vitamin $\mathrm{C}$ continued to fall in this group it is not likely to have arisen from simple diffusion. From data from this group in particular it would be difficult to argue that high plasma vitamin $\mathrm{C}$ in babies born prematurely was due to impaired tissue uptake of this vitamin.

A similar gestation-related decline in vitamin C concentration was shown for amniotic fluid, the composition of which is determined by excretory activity of the developing kidney and lungs. Between 49 and $63 \mathrm{~d}$ the excretion of vitamin $\mathrm{C}$ into amniotic fluid showed a substantial drop, suggesting that placental transport of vitamin $\mathrm{C}$ was no longer providing vitamin $\mathrm{C}$ in excess of fetal requirements. For fetuses in group $\mathrm{A}$ the excretion of vitamin $\mathrm{C}$ into amniotic fluid was so low by day 63 as to suggest that materno-fetal transport was barely sufficient to meet requirements. This is surprising in view of the high concentration of vitamin $\mathrm{C}$ in placenta relative to other tissues, even in late gestation.

\section{Effects of maternal vitamin $C$ intake on plasma and tissue concentrations}

Dietary intake of vitamin $\mathrm{C}$ by dams was also a determinant of fetal plasma and tissue vitamin $\mathrm{C}$ concentrations.

Table 4. Concentration of vitamin $\mathrm{C}$ in tissues of fetuses and pups from mothers given different amounts of vitamin $\mathrm{C}$ during pregnancył (Mean values and standard deviations for the numbers of fetuses specified in Table 2)

\begin{tabular}{|c|c|c|c|c|c|c|c|c|c|}
\hline \multirow[b]{3}{*}{ Diet } & \multirow[b]{3}{*}{ Gestational age } & \multicolumn{8}{|c|}{ Vitamin $\mathrm{C}(\mu \mathrm{mol} / \mathrm{g}$ wet wt $)$} \\
\hline & & \multicolumn{2}{|c|}{ Liver } & \multicolumn{2}{|c|}{ Kidney } & \multicolumn{2}{|c|}{ Lung } & \multicolumn{2}{|c|}{ Heart } \\
\hline & & Mean & SD & Mean & SD & Mean & $S D$ & Mean & SD \\
\hline Moderate vitamin $C(A)$ & $\begin{array}{l}49 d \\
63 d \\
66 d \\
\text { Term }\end{array}$ & $\begin{array}{c}1502^{*} \\
468 \\
376 \\
571\end{array}$ & $\begin{array}{r}310 \\
24 \\
305 \\
72\end{array}$ & $\begin{array}{c}1078^{*} \\
703 \\
457 \\
389\end{array}$ & $\begin{array}{r}174 \\
132 \\
285 \\
54\end{array}$ & $\begin{array}{c}1280^{*} \\
467 \\
445 \\
485\end{array}$ & $\begin{array}{r}192 \\
3 \\
259 \\
105\end{array}$ & $\begin{array}{l}711^{*} \\
540 \\
350 \\
244\end{array}$ & $\begin{array}{r}36 \\
22 \\
284 \\
30\end{array}$ \\
\hline High vitamin $\mathrm{C}(\mathrm{B})$ & $\begin{array}{l}49 d \\
63 d \\
66 d \\
\text { Term }\end{array}$ & $\begin{array}{c}1154 \\
603 \\
490 \\
1046 \dagger\end{array}$ & $\begin{array}{r}154 \\
314 \\
314 \\
44\end{array}$ & $\begin{array}{l}993 \\
887 \\
514 \\
762\end{array}$ & $\begin{array}{r}64 \\
225 \\
252 \\
261\end{array}$ & $\begin{array}{l}804 \\
675 \\
342 \\
828+\end{array}$ & $\begin{array}{r}400 \\
165 \\
158 \\
62\end{array}$ & $\begin{array}{l}695 \\
777 \\
368 \\
475\end{array}$ & $\begin{array}{r}151 \\
68 \\
262 \\
137\end{array}$ \\
\hline
\end{tabular}



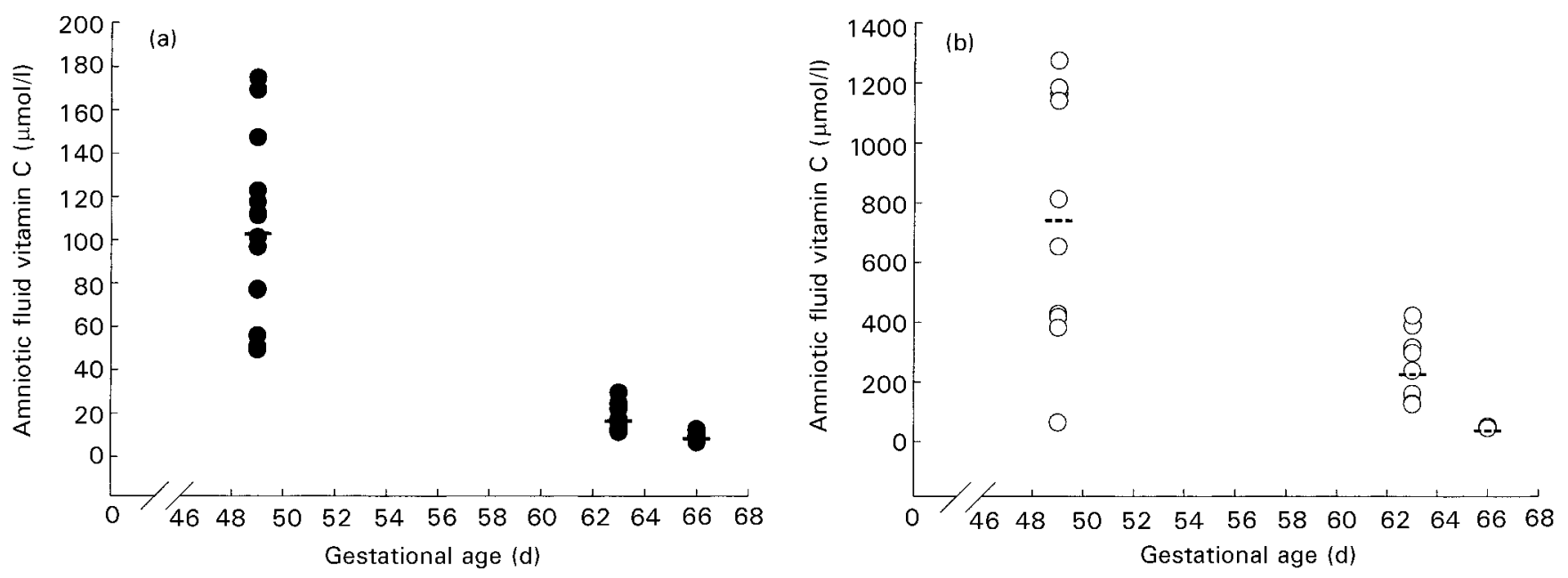

Fig. 5. Effect of gestational age on vitamin C concentrations in amniotic fluid in guinea-pigs fed on either a moderate- (group A, $\bullet$ ) or a high- (group $\mathrm{B}, \mathrm{O}$ ) vitamin $\mathrm{C}$ diet. Values are for individual guinea-pigs, with means indicated by a broken line. Multiple regression analysis showed a significant negative association between amniotic fluid vitamin $\mathrm{C}$ concentration and gestational age for both groups $(P<0 \cdot 001)$. For details of diets and procedures see Table 1 and pp. 485-487.

Throughout gestation, dam concentrations of vitamin $\mathrm{C}$ were higher in the group fed on the high-vitamin $\mathrm{C}$ diet, and this pattern was repeated for the fetuses. The association between fetal and maternal vitamin $\mathrm{C}$ was stronger for the high-vitamin $\mathrm{C}$ group, probably because the range of values was much greater than for the moderate-vitamin $\mathrm{C}$ group. This relationship between dam and fetus is compatible with transport of vitamin $\mathrm{C}$ across the placenta by facilitated diffusion (Choi \& Rose, 1989). High intakes of vitamin C by the mother during pregnancy could therefore increase plasma vitamin $\mathrm{C}$ levels in the newborn and might exacerbate effects of preterm delivery on plasma vitamin $\mathrm{C}$. However, the ratio fetal: maternal plasma vitamin $\mathrm{C}$ fell towards term and showed less of an influence of maternal diet from $66 \mathrm{~d}$. This suggests that the overriding determinant of plasma vitamin $\mathrm{C}$ at birth will be gestational age; shorter gestation would be expected to lead to high plasma vitamin $\mathrm{C}$ levels. This is borne out by the reported inverse relationship between plasma vitamin $\mathrm{C}$ measured within $2 \mathrm{~h}$ of birth and gestational age at delivery (Silvers et al. 1998). It must also be noted that during early gestation, values for the ratio fetal : maternal plasma vitamin $\mathrm{C}$ were much higher in the moderate-vitamin $\mathrm{C}$ intake group than in the high-vitamin $\mathrm{C}$ group. This occurred despite low maternal plasma vitamin $\mathrm{C}$ levels in this group, at times falling below the average for non-pregnant guinea-pigs (Habibzadeh et al. 1986). This suggests that during early gestation there is a drive towards maintaining high fetal plasma vitamin $\mathrm{C}$ concentrations which could occur even at the risk of depleting maternal vitamin C. For this group, which was fed on a commonlyused breeding diet, both maternal and fetal plasma vitamin $\mathrm{C}$ levels at term were lower than the average for nonpregnant guinea-pigs, raising the question of whether the recommended vitamin $\mathrm{C}$ concentrations for such diets are adequate. There is relatively little information regarding plasma vitamin $\mathrm{C}$ concentration during normal pregnancy in human subjects but there is some evidence to suggest a fall as pregnancy proceeds (Baker et al. 1975). A study by
Habibzadeh et al. (1986) suggested that a short-term deficiency of vitamin $\mathrm{C}$ during early pregnancy may affect reproductive performance. There may be other associated effects on maternal or fetal outcome.

Placental vitamin $\mathrm{C}$ levels were less sensitive to differences in maternal intake than were fetal plasma levels. This tissue may regulate the transfer of vitamin $\mathrm{C}$ from mother to placenta differently from the transfer from placenta to fetus. It is curious that the placenta retains such a high concentration of vitamin $\mathrm{C}$ under circumstances of relative fetal deprivation. Transport of vitamin $\mathrm{C}$ across the placenta can be considered as two functions; transport from the mother to the placenta $(\mathrm{M}-\mathrm{P})$ and transport from the placenta to fetus $(\mathrm{P}-\mathrm{F})$. The rate of $(\mathrm{M}-\mathrm{P})$ is evidently

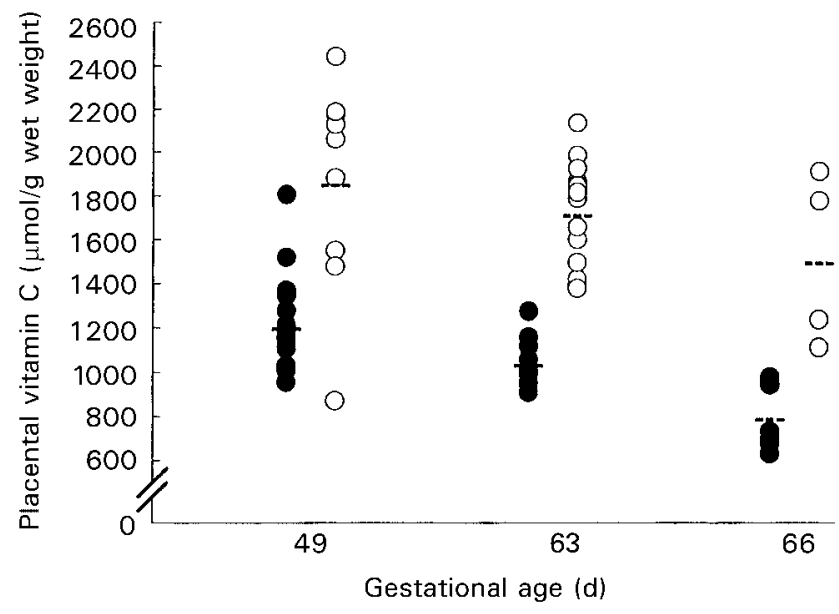

Fig. 6. Placental vitamin $C$ concentrations at different stages in gestation in dams fed on either a moderate- (group $A, \bullet$ ) or a high(group $\mathrm{B}, \mathrm{O}$ ) vitamin $\mathrm{C}$ diet, during pregnancy. Values are for individual guinea-pigs, with means indicated by a broken line. Group B placentas had significantly higher vitamin $C$ concentrations than group $\mathrm{A}$ at all time points $(P<0.001)$. For details of diets and procedures see Table 1 and pp. 485-487. 
higher than $(\mathrm{P}-\mathrm{F})$, as reflected by the high concentrations of vitamin $\mathrm{C}$ found in the placenta. The modest gestational age-related fall in vitamin $\mathrm{C}$ concentrations in the placenta could be due to either a fall in $(\mathrm{M}-\mathrm{P})$ or a rise in $(\mathrm{P}-\mathrm{F})$. Our data support the former, because a gestation-related fall in fetal plasma and amniotic fluid vitamin $\mathrm{C}$ concentrations was detected, which might not be expected had there been a rise in $(\mathrm{P}-\mathrm{F})$ in later gestation.

Evidently, although gestional age is a key determinant of plasma and tissue concentrations of vitamin $\mathrm{C}$ in the developing fetus, maternal vitamin $\mathrm{C}$ intake is also a contributing factor.

The gestation-related decline in plasma and tissue concentrations of vitamin $\mathrm{C}$ is not characteristic of all other vitamins. Fat-soluble vitamins A and $\mathrm{E}$ show a greater fetal accumulation in the last trimester of pregnancy (Zachman, 1989; Dison et al. 1993). Folate, which appears to behave more like vitamin $\mathrm{C}$ in that there is a rapid fetal accumulation early in pregnancy, nevertheless shows an increased rate of transfer during the last weeks of pregnancy (Ek \& Magnus, 1982). The decline in fetal vitamin C late in gestation occurs despite very high placental concentrations, supporting a regulatory role for the placenta. Rapid fetal development early in gestation is likely to create high demand for synthesis of collagen (Myllyla et al. 1978), which is a component of most tissues of the body including skin, tendon, bone, cartilage, blood vessels and teeth and is responsible for providing cell structure and shape. Collagen synthesis is vitamin C-dependent.

In conclusion, high plasma vitamin $\mathrm{C}$ concentrations in premature babies at birth are almost certainly due, primarily, to a fall in plasma and tissue vitamin $\mathrm{C}$ concentration that occurs in the fetus towards term. High intakes of vitamin $\mathrm{C}$ by the mother during pregnancy could contribute to this, but in practice this is of doubtful significance.

\section{References}

Baker H, Frank O, Thomson AD, Langer A, Munves ED, De Angelis B \& Kaminetzky HA (1975) Vitamin profile of 174 mothers and newborns at parturition. American Journal of Clinical Nutrition 28, 56-65.

Berger TM, Rifai N, Avery ME \& Frei B (1996) Vitamin C in premature and full-term human neonates. Redox Report 4, 257262.

Choi J \& Rose RC (1989) Transport and metabolism of ascorbic acid in human placenta. American Physiological Society 257, C110-C113.

Dison PJ, Lockitch G, Halstead AC, Pendray MR, Macnab A \& Wittmann BK (1993) Influence of maternal factors on cord and neonatal plasma micronutrient levels. American Journal of Perinatology 10, 30-35.

Ek J \& Magnus E (1982) Plasma and red cell folate values and folate requirements in formula-fed term infants. Journal of Pediatrics 100, 728-744.

Gutteridge JM (1991) Plasma ascorbate levels and inhibition of the antioxidant activity of caeruloplasmin. Clinical Science 81, 413-417.

Habibzadeh N, Schorah CJ \& Smithells RW (1986) The effects of maternal folic acid and vitamin C nutrition in early pregnancy on reproductive performance in the guinea-pig. British Journal of Nutrition 55, 23-35.

Kelly FJ \& Lubec G (1995) Hyperoxic injury of immature guinea pig lung is mediated via hydroxyl radical. Pediatric Research 38, 286-291.

Kelly FJ, Rickett GM, Hunt AN, Town GI, Holgate ST \& Postle TD (1991a) Biochemical maturation of the guinea pig lung and survival following premature delivery. International Journal of Biochemistry 81, 467-471.

Kelly FJ, Town GI, Phillips GJ, Hogate ST, Roche WR \& Postle AD (1991b) The pre-term guinea-pig: a model for the study of neonatal lung disease. Clinical Science 81, 439-446.

Kime R, Gibson A, Hider R \& Powers H (1996) Chromatographic method for the determination of non-transferrin-bound iron suitable for use on the plasma and broncheoalveolar lavage fluid from preterm babies. Clinical Science 91, 633-638.

Lindeman JHN, Houdkamp E, Lentjes EGWM, Poorthuis BJHM \& Berger HM (1992) Limited protection against iron-induced lipid peroxidation by cord blood plasma. Free Radical Research Communications 16, 285-294.

Lindeman JHN, Lentjes EGWM \& Berger HM (1995) Diminished protection against copper-induced lipid peroxidation by cord blood plasma of preterm and term infants. Journal of Parenteral and Enteral Nutrition 19, 373-375.

Lindeman JHN, Zoeren-Grobben DW, Schrijver J, Speek AJ, Poorthuis BJHM \& Berger HM (1989) The total free radical trapping ability of cord blood plasma in preterm and term babies. Pediatric Research 26, 20-24.

Myllyla R, Kuuti-Svolainen E \& Kivirikko KI (1978) The role of ascorbate in the prolyl hydroxylase reaction. Biochemical and Biophysical Research Communications 83, 441-448.

Pate SK, Lukert BP \& Kipp DE (1996) Tissue vitamin C levels of guinea pig offspring are influenced by maternal vitamin $C$ intake during pregnancy. Journal of Nutritional Biochemistry 7, 525528.

Powers HJ, Loban A, Silvers K \& Gibson AT (1995) Vitamin C at concentrations observed in premature babies inhibits the ferroxidase activity of caeruloplasmin. Free Radical Research Communications 22, 57-65.

Saugstad OD (1996) Mechanisms of tissue injury by oxygen radicals: implications for neonatal disease. Acta Paediatrica 85, $1-4$

Silvers KM, Gibson AT \& Powers HJ (1994) High plasma vitamin $\mathrm{C}$ concentrations at birth associated with low antioxidant status and poor outcome in premature infants. Archives of Disease in Childhood 71, F40-F44.

Silvers KM, Gibson AT, Russel JM \& Powers HJ (1998) Antioxidant activity, packed cell transfusions and outcome in premature infants. Archives of Disease in Childhood 78, F214F219.

Vuilleumier JP \& Keck E (1989) Fluorometric assay of vitamin C in biological materials using a centrifugal analyser with fluorescence attachment. Journal of Micronutrient Analysis 5, 2534.

Zachman RD (1989) Retinol (vitamin A) and the neonate: special problems of the human premature infant. American Journal of Clinical Nutrition 50, 413-424. 


\title{
The Nutrition of the Rabbit
}

\author{
Edited by C de Blas, Departamento de Producion Animal, Universidad Politecnica, Madrid, \\ Spain and Julian Wiseman, Department of Agriculture and Horticulture, University of \\ Nottingham, UK
}

Rabbit production systems are important providers of meat in many parts of the world. The species has many advantages, including rapid growth rate and good reproductive performance. It is adaptable in that it may be reared under intensive conditions, but is also successful under small scale production systems, which are of considerable value in the economics of emerging countries. Although not a ruminant, its digestive system allows it to thrive on high fibre raw materials. The meat has a comparatively healthy low fat image, which is increasingly important to consumers and there appear to be few impediments, such as religious considerations, to rabbit meat consumption.

However, the science of rabbit production has received relatively little attention, although there are recognised rabbit research groups worldwide and a wealth of data exists in a scattered form in the literature. This book brings together that expertise under one cover. It covers a range of topics, from digestive physiology and nutrient/energy allowances to feed formulation and production. The information provided will be an invaluable asset to those involved in rabbit rearing, whether as companion animals or for meat production, and will also provide data of considerable interest to animal nutritionists and zoologists working on rabbits and related mammals.

Contents:

- The Digestive System of the Rabbit

- Digestion of Starch and Sugars

- Protein Digestion

- Fat Digestion

- Fibre Digestion

- Feed Evaluation

- Energy Metabolism and Requirements

- Protein Requirements

- Minerals, Vitamins and Additives

- Influence of the Diet on Rabbit Meat Quality

- Nutrition and Pathology

- Feed Manufacturing

- Feed Formulation

- Feeding Systems for Intensive Production

- Climatic Environment

- Nutritional Recommendations and Feeding Management of Angora Rabbits

- Pet Rabbit Feeding and Nutrition

December 1998352 pages HB

ISBN $085199279 \mathrm{X}$

$£ 55.00$ (US $\$ 100.00$ )

For further information or to order please contact CABI Publishing, UK or an exclusive CABI Publishing distributor in your area.

Please add $£ 2.00$ per book postage and packing (excluding $U K$ ).

\section{CABI Publishing}

CABI Publishing, CAB International, Wallingford, Oxon OX10 8DE, UK

Tel: +44 (0)1491 832111 Fax: +44 (0)1491829292 Email: orders@cabi.org

CABI Publishing, CAB International, 10 East 40th Street, Suite 3203, New York, NY 10016, USA

Tel: +1 2124817018 Fax: +1 2126867993 Email: cabi-nao@cabi.org 